\title{
Presence of Sargassum horneri at Todos Santos Bay, Baja California, Mexico: Its Effects on the Local Macroalgae Community
}

\author{
Giuliana I. Cruz-Trejo ${ }^{1,2}$, Silvia E. Ibarra-Obando ${ }^{1}$, Luis E. Aguilar-Rosas ${ }^{3}$, \\ Miriam Poumian-Tapia1, Elena Solana-Arellano' ${ }^{1}$ \\ ${ }^{1}$ Marine Ecology Department, CICESE, Ensenada, México \\ ${ }^{2}$ Ocean Resources Department, CINVESTAV-IPN, Mérida, México \\ ${ }^{3}$ Instituto de Investigaciones Oceanológicas, Universidad Autónoma de Baja California, Ensenada, México \\ Email: sibarrra@cicese.mx
}

Received 5 August 2015; accepted 27 October 2015; published 30 October 2015

Copyright (C) 2015 by authors and Scientific Research Publishing Inc.

This work is licensed under the Creative Commons Attribution International License (CC BY). http://creativecommons.org/licenses/by/4.0/

(c) (i) Open Access

\section{Abstract}

To describe the annual cycle of Sargassum horneri in Mexican waters, we selected two sites differing in their degree of wave exposure and sediment type: Rincón de Ballenas (RB), and Rancho Packard (RP). From June 2009 to April 2010 we followed the seasonal changes in S. horneri density and biomass along two intertidal transects per site. The effects of this non-indigenous species on the local macroalgae community were assessed by comparing their species composition, density, biomass, species richness, and diversity index in quadrats with and without $S$. horneri. There were significant differences in $S$. horneri density and biomass between sites $(\mathrm{P}<0.001)$. At $\mathrm{RB}$ the invasive alga density average was $2 \pm 0.94$ individual $\mathrm{m}^{-2}$, with a mean biomass of $4 \pm 0.95 \mathrm{~g} \mathrm{DW}$ $\mathrm{m}^{-2}$. At RP, $S$. horneri density average was $10 \pm 0.96$ individual $\mathrm{m}^{-2}$, and mean biomass of $102 \pm$ $0.97 \mathrm{~g} \mathrm{DW} \mathrm{m}^{-2}$. At $\mathrm{RB}$, the invasive alga promoted a significant reduction in the four selected structural variables, and the corticated macrophytes and the foliose functional forms were severely reduced. At $\mathrm{RP}$, there were only marginally significant effects $(\mathrm{P}=0.06)$ of $S$. horneri presence on the local macroalgae community, and higher density, biomass, and diversity values were found when S. horneri was present. Most of the functional forms were found, even if the invasive alga was present. At both locations, the highest biomass corresponded to the articulated calcareous functional form. These contrasting results could be due to the fact that the native macroalgae community has already been altered by the early invasion of $S$. muticum, with the most resilient species and functional forms remaining in place. One of the most important changes we noticed is the severe reduction of the canopy forming species at both sites.

${ }^{*}$ Corresponding author.

How to cite this paper: Cruz-Trejo, G.I., Ibarra-Obando, S.E., Aguilar-Rosas, L.E., Poumian-Tapia, M. and Solana-Arellano, E. (2015) Presence of Sargassum horneri at Todos Santos Bay, Baja California, Mexico: Its Effects on the Local Macroalgae Community. American Journal of Plant Sciences, 6, 2693-2707. http://dx.doi.org/10.4236/ajps.2015.617271 
Keywords

\author{
Annual Cycle, Community Structure, Diversity Index, Functional Forms, Invasive Alga, Species \\ Richness
}

\title{
1. Introduction
}

Non-indigenous species (NIS) represent a major concern to marine scientists as the ecosystem in which they arrive in is modified adversely. This change takes place through the ecological interactions they establish with the native species and through direct or indirect physical or chemical changes in the habitat itself. The speed of habitat change is also coupled to the stability or resilience of the ecosystem, so the impact can have different scales in space and time [1].

While experimental work supports the idea that diverse communities show greater resistance to invasion, it is not clear if this results from resource use complementarity, or from an increasing occurrence of suppressive species in more diverse communities [2]. To understand the mechanisms driving this response, interest has shifted from species richness to the functional roles that species or groups of species play. Functional groups are defined as non-phylogenetic grouping of species that perform similarly in an ecosystem based on a set of common biological attributes. Functional groups can be defined in relation to either the contribution of species to ecosystem processes, such as carbon or water cycling, or the response of species to changes in environmental variables, such as climatic variables or disturbance [3]. The number and identity of functional groups within a community may dictate the level of invasibility, implying that the invasion of a coastal habitat will only be promoted through loss of a whole functional group rather than the loss of one or a few members of that group [2].

As marine ecosystems are relatively open, with fewer limits than terrestrial systems to organism dispersal and energy flow, the irreversible impacts of exotic species have profound consequences on ecological systems [2]. Macroalgae are considered to be especially worrying NIMS (non-indigenous marine species) as they may alter ecosystem structure and function by monopolizing space, developing into ecosystem engineers, changing food webs, and spreading beyond their initial point of introduction through efficient dispersal capacities [4] [5]. The success of a non-indigenous species depends on its mode of reproduction, growth rate and dispersive potential [6] [7].

The fucoid genus Sargassum is monoecious, highly fecund, and possesses vesicles that allow the reproductive fronds produced annually to drift with currents and inoculate new locations [7]-[9]. Due to its ability to colonize hard and soft substrata, the total area of marine sediments open to occupation by members of the genus Sargassum is vast, and cumulative habitat modification could be very significant [10]. The main barrier to colonization of the rock is the presence of algal cover [11].

Once established, these species can accumulate high biomass and thus become a strong competitor for space and light [12]. Sargassum invasions have significantly impacted the structure of indigenous algal communities in North America and Europe, through competitive displacement and/or exclusion [7] [13]. Several studies have reported the reduction of functional groups, like the thick leathery and coarsely branched algae and native understory algae through strong competitive interactions with adult individuals of S. muticum [7] [14]-[17].

Sargassum horneri is native from Asia, and distributed in Japan, Korea, Hong Kong (China), Chinese Taipei and China Mainland [18]. It was observed in Catalina Island, California, in 2003 [19]. In Baja California, wellestablished populations of this species were observed in Todos Santos Bay in 2007 [20], from where it had extended along the temperate waters of the Baja California Peninsula [21]. However, no description exists of the population structure of $S$. horneri in Mexican waters. For this reason, we decided to study the annual growth cycle inside the Todos Santos bay. We were also interested in assessing the ecological impact of this non-indigenous algal species on the structure of the local community of macroalgae. For this purpose, we selected two locations that differed in substrate type and wave exposure degree, and measured the seasonal influence of Sea Surface Temperature (SST), Photosynthetically Active Radiation (PAR), and air-exposure hours, on S. horneri density and biomass. Simultaneously, we determined the changes in the species composition, density, and biomass of the local macroalgae community. Algal species were classified into functional groups to identify if their number and types differed as a function of the presence or absence of $S$. horneri. We expected S. horneri to be better represented in the most exposed site, where its high density and biomass would result in a significant re- 
duction of macroalgae, density, and biomass, and a change in species composition. We anticipated the loss or reduction of the canopy forming species, representing the more morphologically complex functional forms.

\section{Materials and Methods}

\subsection{Study Site}

The Todos Santos bay is located about $130 \mathrm{~km}$ south of the USA-Mexico border, on the northwest coast of the Baja California peninsula, at $\sim 31^{\circ} 47^{\prime} \mathrm{N} ; 116^{\circ} 43^{\prime} \mathrm{W}$ (Figure 1).

The NW oceanic boundary is defined by the ridge of a broad shoal between the Todos Santos islands and the mainland shoreline. The SW boundary is defined as the shortest distance between a prominent point, known as Punta Banda, and the Todos Santos islands, and is marked by a $6 \mathrm{~km}$ wide submarine canyon. The bay has a surface area of $\sim 240 \mathrm{~km}^{2}$. Maximum depth within the bay is $\sim 100 \mathrm{~m}$, except for the canyon, reaching to $400 \mathrm{~m}$ and draining down the continental slope [22].

Winds dominate the coastal circulation. Prevailing northwesterly winds, during spring and summer, drive water into the bay from the NW. Only during some winter storms and offshore Santa Ana conditions, water enters from the southwestern [23]. There is an apparent convergence zone within the bay, near the mouth of the Punta Banda estuary, along the eastern shore [24]. Sediment transport into and within the bay follows the same circulation pattern [25]. The bay is under the upwelling influence during periods of NW winds, a prominent feature of much of the Pacific coast of the USA and northern Baja California [26], and some authors have documented the influence of the local upwelling on water properties near the mouth during the springtime upwelling period [22] [27].

The two selected study sites, Rincón de Ballenas (RB), and Rancho Packard (RP), are located in the protected side of the Punta Banda peninsula, which is made up of shale and sandstone, forming high, almost vertical cliffs, which are interrupted locally by small pocket beaches made out of boulders [28]. Wave turbulence and littoral currents separate the material supplied by cliff erosion, allowing only grain sizes greater than $3.5 \phi$ (coarse fraction) to be deposited on the beach, while smaller sizes (fine fraction) are suspended and transported offshore [28]. Loose gravel predominates at Rincón de Ballenas and hard rock at Rancho Packard (Figure 1) [28].

The west coast of Baja California is characterized for having a mixed semidiurnal tidal cycle, with astronomical tides of higher amplitude during winter, season in which the strong storms originate bigger waves. The sum

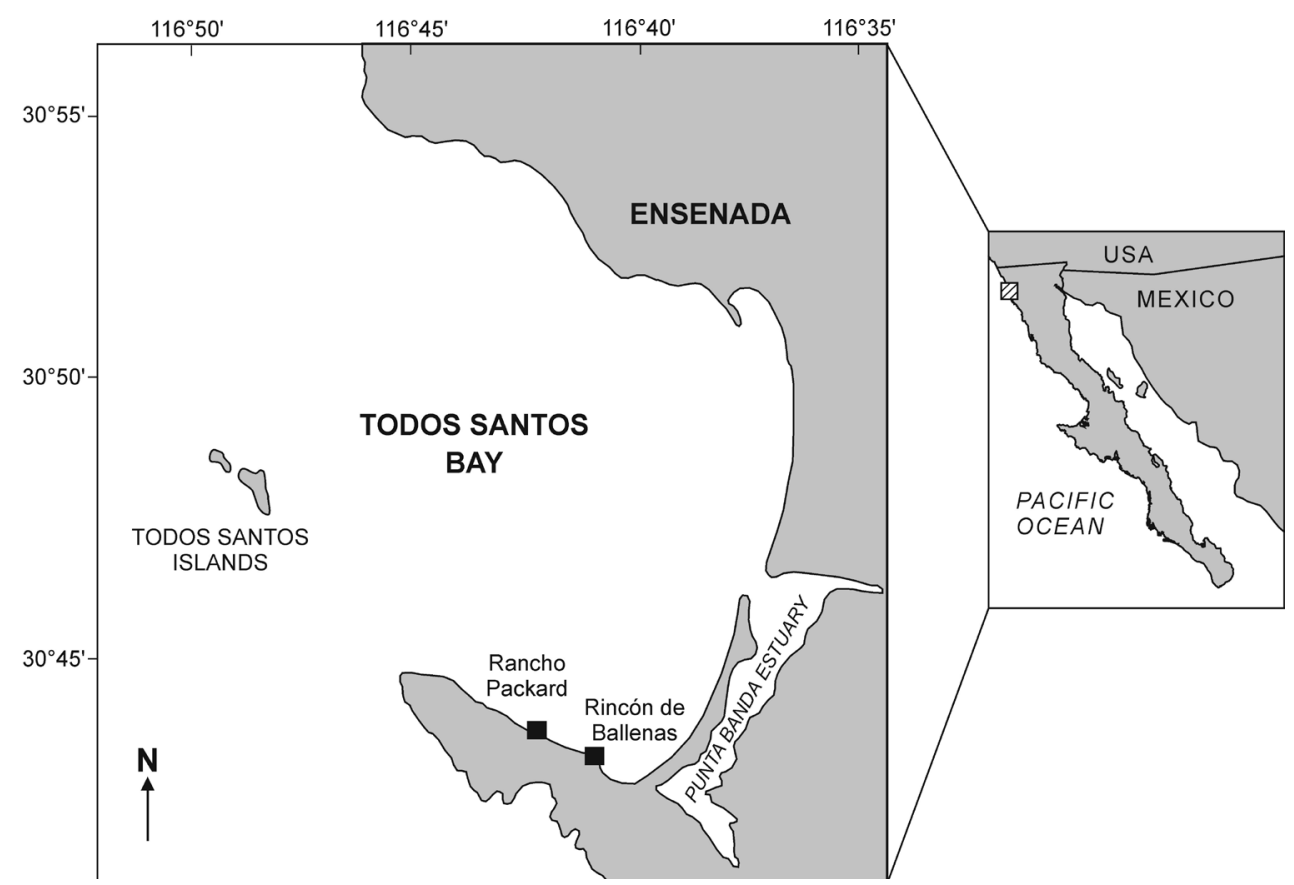

Figure 1. Map of the Baja California peninsula, indicating where the city of Ensenada is located. The inset shows the Todos Santos Bay and the two sampling stations in the protected side of the Punta Banda point. 
of these two components results in a larger total wave amplitude. As a consequence, exposure hours are greater during winter. Of our two study sites, RP is more exposed to waves, than RB [29].

\subsection{Sampling Design}

Sampling took place from June 2009 to April 2010 during the Mean Lower Low Water tidal level (MLLW). Each season was represented by two months: June and July 2009, represented summer; October and November, autumn; December 2009 and January 2010, for winter, and March and April 2010, represented spring.

At each site we installed two transects perpendicular to the shore, separated by about $100 \mathrm{~m}$. Their length and depth varied as a function of the topography. At RB, S. horneri was distributed between -0.2 and $-0.8 \mathrm{~m}$ MLLW, corresponding to the low intertidal level; at RP, its distribution was between +0.5 and $-0.2 \mathrm{~m}$ MLLW, in the middle and high intertidal levels (Figure 2).

\subsection{Field Work}

In order to cover the whole transect, samples were collected in the following manner; in every visit to the field we placed a $10 \mathrm{~m}$ rope along each transect, with marks every $0.5 \mathrm{~m}$. At the beginning of every season, ten 0.25 $\mathrm{m}^{2}$ quadrats were collected every meter starting at the 0 distance, and in the second seasonal visit, ten samples were also collected every meter, but starting at the $0.5 \mathrm{~m}$ mark.

Sampling was destructive, following the methodology described by [29]. Macroalgae were detached from the
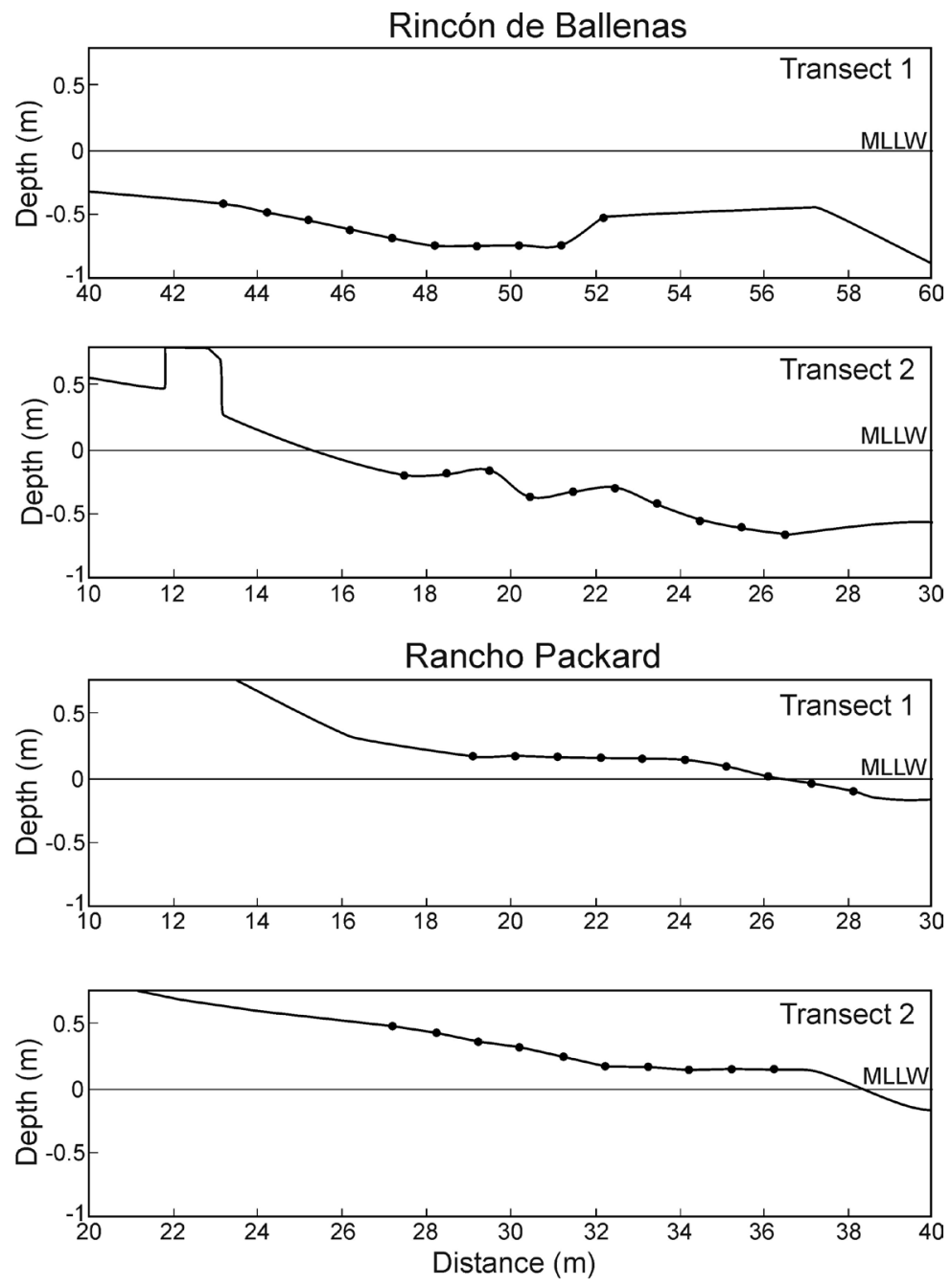

Figure 2. Vertical distribution of $S$. horneri at each of the established transects. 
substrate by hand. All collected material was placed in labeled plastic bags, kept cool until arrival to the laboratory. Once in the lab, macroalgae were frozen until processing.

Sea Surface Temperature (SST) and Photosynthetically Active Radiation (PAR) data from May 2009 to May 2010 were downloaded from NASA's Ocean Color Satellite (http://oceancolor.gsfc.nasa.gov/seadas/). The use of the MODIS sensor provides a $4 \mathrm{~km}$ resolution, so the same data set was used for both sampling sites. For every site and sampling depth, we assessed the seasonal variations in tidal exposure, adding the number of hours that the sea level was lower than the selected reference level (Sea Level Laboratory, CICESE).

\subsection{Laboratory Work}

Macroalgae were defrosted and rinsed with fresh water to remove salts and sediment. Later, placed in plastic trays, and with tweezers, all epiphytic material, whether vegetal or animal, was removed. Algae were first separated into groups: Chlorophyta, Phaeophyta, and Rhodophyta, and then, all members of each group were identified at the species level. For this, histological cuts were performed, and tissue characteristics were analyzed under microscope. We used the taxonomic keys and classification system of [30]. Density was expressed as No. individuals of each species $\mathrm{m}^{-2}$. Each species was oven dried at $60^{\circ} \mathrm{C}$ for 24 hours, and weighed $( \pm 0.1 \mathrm{~g})$ to determine its biomass, expressed as $\mathrm{g} \mathrm{DW} \mathrm{\textrm {m } ^ { - 2 }}$. Average density and biomass values were determined per site, depth, and month. Species were classified infunctional groups following [31], as: filamentous algae, foliose algae, corticated foliose algae, corticated macrophytes, leathery macrophyes, articulated calcareous algae, and crustose algae.

\subsection{Data Analyses}

S. horneri density and biomass data were analyzed using non-parametric statistics, since data did not followed a normal distribution. Significant differences between sites were explored with the U Mann-Whitney test. Differences among depths and months were analyzed with a one-way non-parametric ANOVA, Kruskall-Wallis. When non-significant differences between depth levels were found, such levels were pooled together to increase the power of the statistical tests [32].

The tendency between density and biomass with sea surface temperature, irradiance, and air exposure hours, was analyzed with the Spearman rank correlation test [33]. For all statistical analyses alpha was set at 0.05 , and tests were run using the program STATISTICA 7 for Windows (2002).

\subsection{Community Analyses}

To determine community diversity, we used two attributes of community structure: species richness $(S)$, and the Shannon-Wiener diversity index $\left(H^{\prime}\right)[34]$ :

$$
H^{\prime}=-\sum_{i} \rho_{i}\left(\log p_{i}\right)
$$

where $\rho_{i}$ is the proportion of the total count arising from the ith species.

Both attributes were assessed when S. hornerii was present, and absent. Differences in $H^{\prime}$ under both conditions were tested with Hutchinson test [33].

We analyzed the spatial distribution of the functional groups when S. horneri was present, or absent, using their biomass values. For this, a non-metric MDS using the package "Vegan” for R platform was used [35].

\section{Results}

Following the annual cycle of maximum values during summer, and minimum values during winter, surface water temperature varied between $15.5^{\circ} \mathrm{C}$ and $21.1^{\circ} \mathrm{C}$, and irradiance between 22.8 and $55.2 \mathrm{~mol} \cdot \mathrm{m}^{-2} \cdot \mathrm{d}^{-1}$. Air exposure hours varied by one order of magnitude between sites, with a total of $77 \pm 0.5$ hours at RB, and $685 \pm$ 53 hours at RP. Winter was the season with more exposure hours at RB, and spring had the highest number of exposure hours at RP.

We found highly significant differences in annual mean $S$. horneri density and biomass between sites $(\mathrm{P}<$ $0.001)$, but not between tidal depths at any site ( $P>0.05)$, and only at RP there were significant differences between sampled seasons $(\mathrm{P}<0.05)$. At RB the invasive alga was present during October, November, and March, with an irregular distribution along the sampled depths. Its average density was $2 \pm 0.94$ individual $\mathrm{m}^{-2}$, and av- 


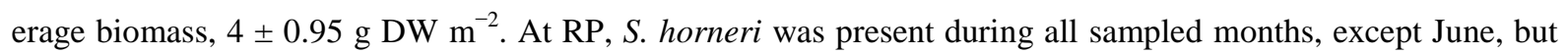
because of bad weather we could not collect samples in April. Also at this site, $S$. horneri vertical distribution was irregular. Average density was $10 \pm 0.96$ individual $\mathrm{m}^{-2}$, with the lowest value during summer, $4 \pm 0.9$ individual $\mathrm{m}^{-2}$, and the highest during autumn, $17 \pm 0.98$ individual $\mathrm{m}^{-2}$. Average biomass for all the study period at $\mathrm{RP}$ was $102 \pm 0.97 \mathrm{~g} \mathrm{DW} \mathrm{m}^{-2}$, with the lowest values in summer, $12 \pm 0.96 \mathrm{~g} \mathrm{DW} \mathrm{m}^{-2}$, and the highest in spring, $292 \pm 0.98 \mathrm{~g} \mathrm{DW} \mathrm{m}^{-2}$.

At RB there were no significant correlations between $S$. horneri density and biomass with the environmental variables, but at RP, S. horneri density and biomass were negatively correlated with SST: $(r=-0.34, \mathrm{P}<0.001)$, and $(r=-0.53, P<0.001)$ respectively; biomass was also negatively correlated with PAR $(r=-0.25, P<0.05)$. Air exposure hours yield no significant correlations with the biological data set either at RB or at RP.

\subsection{Community Structure}

A total of 39 macroalgal species was recorded during this study, of which 23 species were Rhodophyta, 11 Phaeophyta, and 5 Chlorophyta. The highest species richness corresponded to RB, with 29 species, while 25 species characterized RP. Highly significant differences between sites were found for macroalgae density ( $<$ 0.001 ), and biomass $(\mathrm{P}<0.001)$ : $10 \pm 0.9$ individuals $\mathrm{m}^{-2}$, and $66 \pm 0.98 \mathrm{~g} \mathrm{DW} \mathrm{m}^{-2}$, at $\mathrm{RB}$, versus $14 \pm 0.97$ individuals $\mathrm{m}^{-2}$, and $120 \pm 0.96 \mathrm{~g} \mathrm{DW} \mathrm{m}^{-2}$ at RP.

Of the 29 macroalgae species recorded at RB, the Rhodophyta were the most diverse, with 16 species, followed by the Phaeophyta with 9, and the Chlorophyta with 4 species (Table 1).

Table 1. List of macroalgae species found at Rincón de Ballenas, between June 2009 and April 2010, when S. horneri was present (+), or absent (-). Their functional form was determined according to [31].

\begin{tabular}{|c|c|c|c|}
\hline Division & Species & Functional form & Condition \\
\hline \multirow{4}{*}{ Chlorophyta } & Codium fragile & Corticated macrophyte & $(-)$ \\
\hline & Ulva californica & Foliose & $(-)$ \\
\hline & Ulva fasciata & Foliose & $(-)$ \\
\hline & Ulva nematoidea & Foliose & $(-)$ \\
\hline \multirow{4}{*}{ Phaeophyta } & Colpomenia sinuosa & Corticated macrophyte & $(-)$ \\
\hline & Colpomenia tuberculata & Corticated macrophyte & $(-)$ \\
\hline & Dictyota flabellata & Corticated foliose & $(+)(-)$ \\
\hline & Dictyopteris undulata & Corticated foliose & $(+)(-)$ \\
\hline \multirow{21}{*}{ Rhodophyta } & Petrospongium rugosum & Crustose & $(-)$ \\
\hline & Sargassum muticum & Leathery macrophyte & $(+)(-)$ \\
\hline & Silvetia compressa & Leathery macrophyte & $(+)$ \\
\hline & Sphacelaria californica & Filamentous & $(-)$ \\
\hline & Zonaria farlowii & Corticated foliose & $(+)(-)$ \\
\hline & Centroceras clavulatum & Corticated macrophyte & $(-)$ \\
\hline & Chondria californica & Corticated macrophyte & $(-)$ \\
\hline & Chondria decipiens & Corticated macrophyte & $(-)$ \\
\hline & Chondrocanthus canaliculatus & Corticated macrophyte & $(-)$ \\
\hline & Corallina officinalis & Articulated calcareous & $(+)$ \\
\hline & Corallina polysticha & Articulated calcareous & $(-)$ \\
\hline & Corallina vancouverensis & Articulated calcareous & $(+)(-)$ \\
\hline & Cryptopleura ramosa & Foliose & $(-)$ \\
\hline & Endarachne binghamiae & Corticated macrophyte & $(-)$ \\
\hline & Hypnea valentiae & Corticated macrophyte & $(-)$ \\
\hline & Jania crassa & Articulated calcareous & $(+)(-)$ \\
\hline & Jania rosea & Articulated calcareous & $(+)(-)$ \\
\hline & Laurencia pacifica & Corticated macrophyte & $(+)(-)$ \\
\hline & Lithotrix aspergillum & Articulated calcareous & $(+)(-)$ \\
\hline & Pterocladiella capillacea & Corticated macrophyte & $(+)(-)$ \\
\hline & Smithora naiadum & Foliose & $(-)$ \\
\hline
\end{tabular}


Densities were higher for Corallina officinalis, and Sargassum muticum. The highest biomass values corresponded to the red alga Corallina officinalis, and to the green alga Ulva fasciata. The analysis per group shows that density was slightly higher for the red algae, $8.23 \pm 0.73$; followed by the brown, $7.55 \pm 1.32$, and lower for the green algae, with $7 \pm 0.86$ individuals $\mathrm{m}^{-2}$. With respect to biomass, the green algae showed the highest values with $163 \pm 72.8 \mathrm{~g} \mathrm{DW} \mathrm{m}^{-2}$, followed by the red, $75.76 \pm 25.5$, and the brown algae, $41.3 \pm 16.09 \mathrm{~g} \mathrm{DW} \mathrm{m}^{-2}$. At RP, there were 14 species of Rhodophyta, 7 species of Phaeophyta, and 4 Chlorophyta (Table 2).

The red algae with highest density were Corallina frondescens, Centroceras clavulatum, and Lithothrix aspergillum, and the brown algae Dictyopteris undulata, and Petroglosum rugosum. The species with highest biomass were the red algae: Lithothrix aspergillum, Corallina frondescens, C. pinnatifolia, and Centroceras clavulatum. At the group level, density decreased from the brown, to the red, and the green algae: $12.57 \pm 2.34$; $10.66 \pm 1.67$, and $6 \pm 1.73$ individuals $\mathrm{m}^{-2}$ respectively. The red algae had the highest biomass: $133.86 \pm 32.9$, followed by the brown, $56 \pm 7.1$, and the green, $8 \pm 1.2 \mathrm{~g} \mathrm{DW} \mathrm{m}^{-2}$.

\subsubsection{Influence of $S$, horneri at RB}

The most frequently present macroalgae had the greatest contribution in determining the community structure: Dictyota flabellata, Dictyopteris undulata, and Sargassum muticum, among the brown algae; Corallina vancouverensis, Hypnea valentiae, Jania rosea, and Laurencia pacifica, among the red algae. Peak density values were for Corallina officinalis and Laurencia pacifica, when S. horneri was present; when it was absent, highest density values were for S. muticum. When S. horneri was present, Corallina officinalis, and Jania rosea had the greatest biomass; when S. horneri was absent, peak biomass values corresponded to Ulva fasciata, and Ulva californica.

Table 2. List of macroalgae species found at Rancho Packard, between June 2009 and April 2010, when S. horneri was present (+), or absent (-). Their functional form was determined according to [31].

\begin{tabular}{|c|c|c|c|}
\hline Division & Species & Functional form & Condition \\
\hline \multirow{4}{*}{ Chlorophyta } & Codium fragile & Corticated macrophyte & $(+)$ \\
\hline & Codium hubbsi & Corticated macrophyte & $(-)$ \\
\hline & Ulva californica & Foliose & $(-)$ \\
\hline & Ulva nematoidea & Foliose & $(+)(-)$ \\
\hline \multirow{7}{*}{ Phaeophyta } & Colpomenia sinuosa & Corticated macrophyte & $(+)(-)$ \\
\hline & Dictyopteris undulata & Corticated foliose & $(+)(-)$ \\
\hline & Dictyota flabellata & Corticated foliose & $(+)(-)$ \\
\hline & Petrospongium rugosum & Crustose & $(+)(-)$ \\
\hline & Sargassum muticum & Leathery macrophyte & $(+)(-)$ \\
\hline & Silvetia compressadeliquescens & Leathery macrophyte & $(-)$ \\
\hline & Zonaria farlowii & Corticated foliose & $(+)(-)$ \\
\hline \multirow{14}{*}{ Rhodophyta } & Amphiroa zonata & Articulated calcareous & $(+)(-)$ \\
\hline & Centroceras clavulatum & Corticated macrophyte & $(+)(-)$ \\
\hline & Corallina frondescens & Articulated calcareous & $(+)(-)$ \\
\hline & Corallina pinnatifolia & Articulated calcareous & $(+)$ \\
\hline & Corallina vancouverensis & Articulated calcareous & $(+)(-)$ \\
\hline & Endarachne binghamiae & Corticated macrophyte & $(+)$ \\
\hline & Hypnea valentiae & Corticated macrophyte & $(+)(-)$ \\
\hline & Laurencia pacifica & Corticated macrophyte & $(+)(-)$ \\
\hline & Lithrotrix aspergillum & Articulated calcareous & $(+)(-)$ \\
\hline & Mazzaella affinis & Corticated macrophyte & $(-)$ \\
\hline & Mazzaella leptorhynchus & Corticated macrophyte & $(+)(-)$ \\
\hline & Pterocladia caloglossoides & Corticated macrophyte & $(+)$ \\
\hline & Pterocladia californica & Corticated macrophyte & $(+)$ \\
\hline & Pterocladia capillacea & Corticated macrophyte & $(+)(-)$ \\
\hline
\end{tabular}


Macroalgae density showed significant differences between the $S$. horneri presence and absence condition (P $<0.01$ ), with a mean of $2.977 \pm 4.33$ individuals $\mathrm{m}^{-2}$, under presence condition, and $9.647 \pm 2.232$ individuals $\mathrm{m}^{-2}$ when $S$. horneri was absent. The same was true for macroalgae biomass $(\mathrm{P}<0.01)$, with a mean of $18.125 \pm$ $28.99 \mathrm{~g} \mathrm{DW} \mathrm{m}^{-2}$ for the invasive alga presence condition, and $76.428 \pm 48.75$ for the absence condition. Species richness (S) was higher when $S$. horneri was absent, with 28 species, than when the invasive algae was present, 13 species. Also, the diversity index $\left(H^{\prime}\right)$, was higher when $S$. horneri was absent, 0.884 , than when it was present, $0.281(\mathrm{P}<0.0001)$.

There were highly significant differences in macroalgae density through time $(\mathrm{P}<0.01)$, with peak values between October and December, with values ranging between 8 and 13 individuals $\mathrm{m}^{-2}$ (Figure 3(a)). Macroalgae biomass also showed significant differences through time $(\mathrm{P}<0.01)$, with a first peak in November, and a second peak in March, for both presence-absence conditions (Figure 3(b)). Species richness $(S)$ was highest in June, under $S$. horneri absence, and in November, under $S$. horneri presence (Figure 3(c)). The species diversity
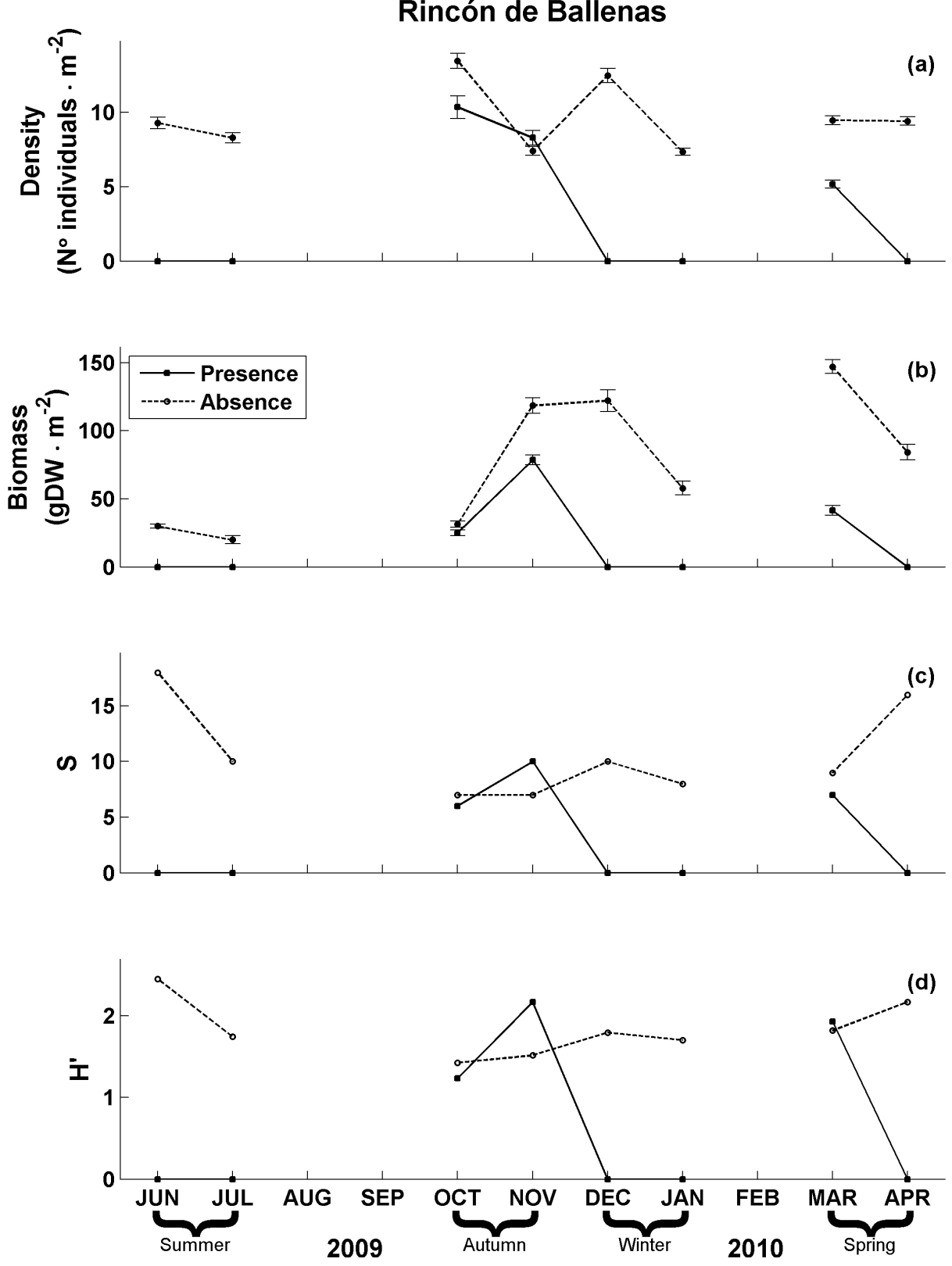

Figure 3. Seasonal variations in the selected structural variables in quadrats with and without S. horneri at RB. 
index, $H^{\prime}$, peaked in November when the invasive alga was present, and in June and April when it was absent, these differences being highly significant $(\mathrm{P}<0.001)$ (Figure 3(d)).

The functional form of each species, and whether it was found when $S$. horneri was present (+), absent (-), or under both conditions $(+)(-)$, is indicated in Table 1. It can be noticed that the corticated macrophytes and the foliose functional forms were the most affected, as the 14 species contained in these groups could only be found when the invasive alga was absent.

The MDS shows, to the left, a compact group formed by the low biomass values of all functional groups present; however, to the right, it can be noticed that the articulated calcareous reached the higher biomass values, regardless of whether the invasive algae was present, or absent (Figure 4).

\subsubsection{Influence of S. horneri at RP}

The macroalgae with the highest contribution to the community structure were: Dyctiopteris undulata, Sargassum muticum, Zonaria farlowii, and Dictyota flabellata, among the brown algae, and: Lithothrix aspergillum, Centroceras clavullatum, and Corallina vancouverensis, among the red algae.

When S. horneri was present, the species with more individuals per $\mathrm{m}^{2}$ were: Centroceras clavulatum, Corallina frondescens, Mazzaella leptorhynchus, and Dictyopteris undulata. When S. horneri was absent, Lithothrix aspergillum and Petrospongium rugosum were the species with highest densities. When S. horneri was present, the algae with the highest biomass values were: Corallina frondescens, and Lithothrix aspergillum. This last species, also had the highest biomass when $S$. horneri was absent, followed by Centroceras clavullatum.

The comparison of macroalgae density between the presence-absence conditions was slightly marginal $(\mathrm{P}=$ 0.06). Mean values were $9.641 \pm 5.52$ individual $\mathrm{m}^{-2}$ when $S$. horneri was present and $4.880 \pm 6.88$ individual $\mathrm{m}^{-2}$ when it was absent. The same significance level $(\mathrm{P}=0.06)$ was found for the biomass comparison, with means of $74.489 \pm 60.21 \mathrm{~g} \mathrm{DW} \mathrm{m}^{-2}$ under presence of the invasive alga, and $46.239 \pm 82.33 \mathrm{~g} \mathrm{DW} \mathrm{m}^{-2}$ when it was absent. Species richness was similar when $S$. horneri was present, with 22 species, at when it was absent, 21 species. However, there were significant differences in the diversity index, with a higher value when the invasive alga was present, 0.740, than when it was absent $0.676(\mathrm{P}<0.005)$. We also found that the selected variables showed changes as a function of time, with peak values in October, when the invasive alga was present, and in June when it was absent $(\mathrm{P}<0.001)$ (Figure 5).

At this site, most of the species were present independently of the presence of S. horneri, with only three species, all with different functional forms, being affected by its presence (Table 2).

The MDS showed that, as in RB, the articulated calcareous group reaches the highest biomass values, followed by the corticated macrophytes (Figure 6).

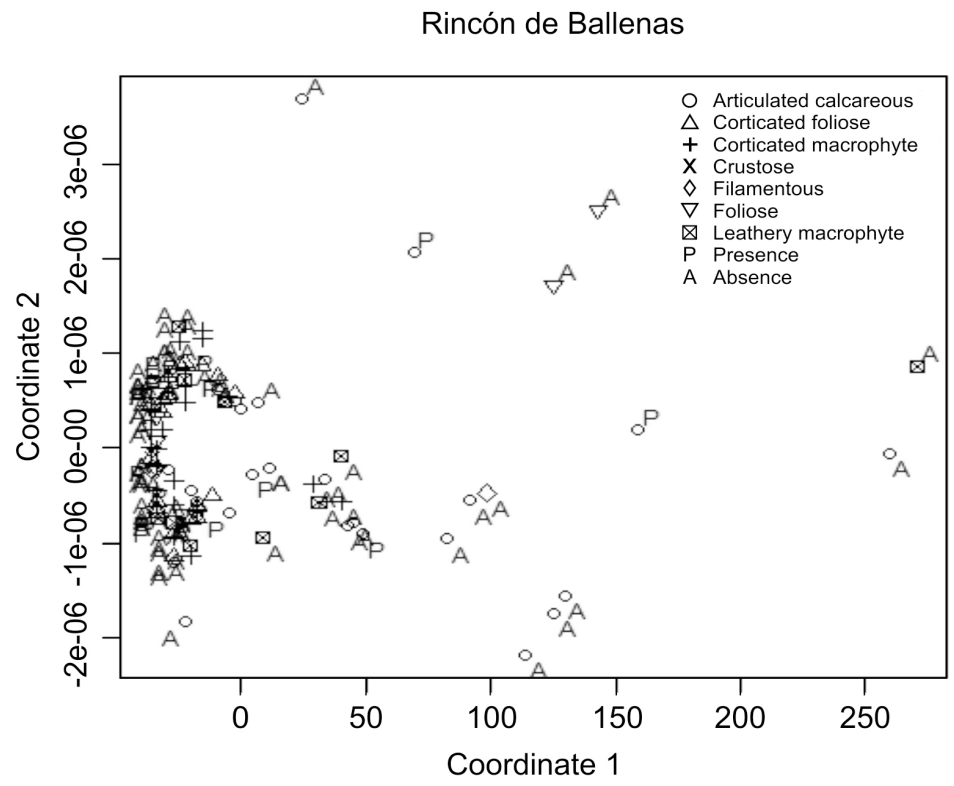

Figure 4. Distribution of the macroalgae functional forms at RB along the two coordinate principal axes. 

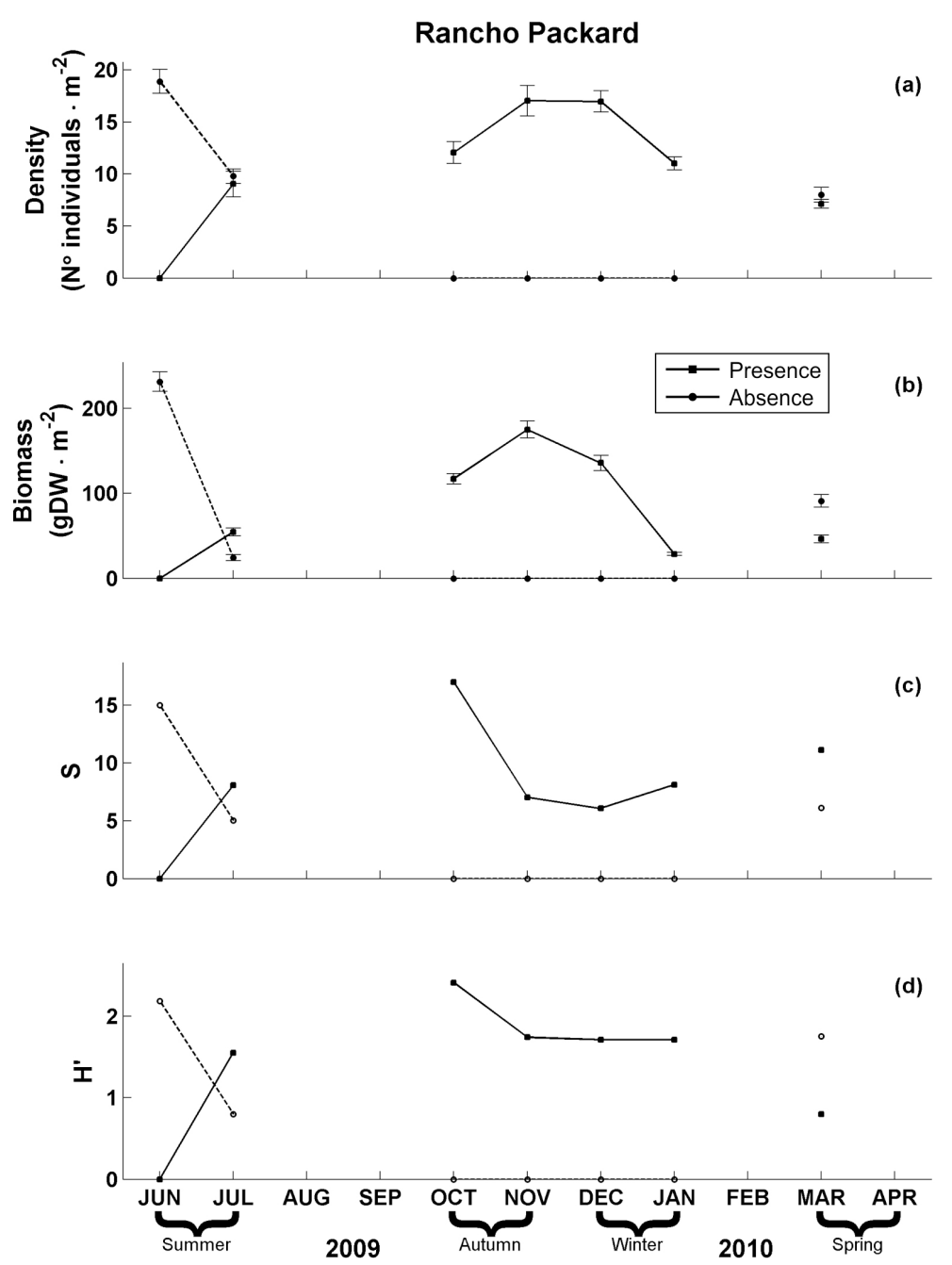

Figure 5. Seasonal variations in the selected structural variables in quadrats with and without S. horneri at RP.

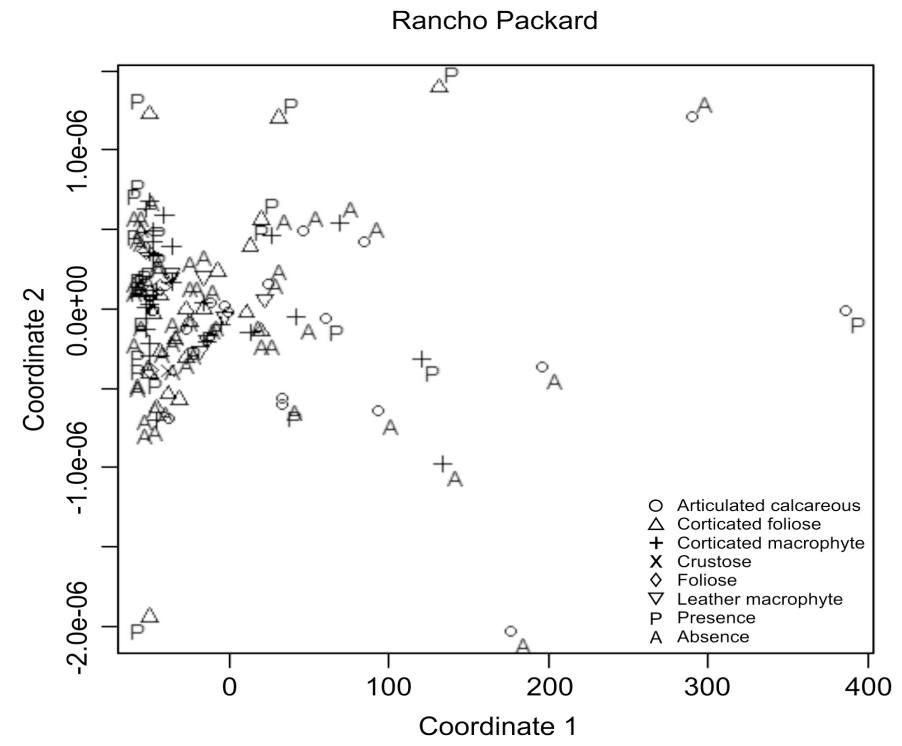

Figure 6. Distribution of the macroalgae functional forms at RP, along the two coordinate principal axes. 


\section{Discussion}

Our results show that there are important site differences in the presence of $S$. horneri inside the Todos Santos bay and its effects on the macroalgae community. At Rincón de Ballenas, the invasive alga was not present all year round, and had low density and biomass values. However, its presence resulted in a significant reduction in the macroalgae density, biomass, species richness and diversity. The corticated macrophytes and the foliose functional forms were severely reduced by the presence of the invasive alga. On the other hand, at Rancho Packard, the presence of $S$. horneri was more continuous throughout the year, and this non-indigenous species reached high density and biomass values. Despite this, there only were marginally significant effects of its presence on the local macroalgae community, and higher density, biomass, and diversity values were found when $S$. horneri was present. Most of the functional forms were represented, even when $S$. horneri was present. Despite these notorious site differences, at both locations, the highest biomass corresponded to the articulated calcareous functional form.

With respect to sites differences, we know that RB is characterized by reduced wave exposure and soft sediment, represented by loose gravel. In contrast, at RP, wave exposure is slightly higher and the substrate is represented by solid rock. Although $S$. horneri has the rare ability to colonize both, hard and soft substrate [10], our data indicate that at the Todos Santos bay, S. horneri grows better on hard substrate. This is in agreement with [7], whoat Limfjorden, Denmark, found a strong correlation between the cover of S. muticum and the presence of hard substrate. Although we did not find significant differences with depth, [7], found that the difference in cover between shallow, 0 - $2 \mathrm{~m}$, and deep, 2 - $6 \mathrm{~m}$, waters, was regulated by the amount of hard substrate.

Water movement has been considered a seasonally important variable which affects standing biomass, thallus size, morphology and, possibly, fertility [36] [37]. Although we did not made direct measurements of water movement, [29] used numerical simulation models to predict ocean surface waves inside the Todos Santos bay, and results of her study show a higher wave energy at RP, where we found the healthier populations of $S$. horneri. However, in Obama bay, Japan, [38] found that the $S$. horneri populations from the sheltered coast had longer primary laterals, and plants had higher weight, than those from the exposed shore. In situ measurements of wave exposure are needed at Todos Santos bay, to determine if our two study sites can be considered to be in a protected shore. For the northern coast of Spain [9], found that wave exposure was not significant for S. muticum growth and survivorship. In contrast, [39], for the foliose algae of South Wales, and [37], for the populations of S. polyceratium in Curaçao, found that foliose algae were more abundant where wave-action was greater and during the cooler months of the year.

Reference [39] also found that algal survival was greater and growth was faster under conditions of increased moisture, decreased emersion, and decreased temperatures and light regimes during low tide. However, in our study we could not find a significant correlation between S. horneri density and biomass with tidal exposure, despite the high number of exposure hours at RP. The fact that $S$. horneri grows at the high intertidal at RP (Figure 2), and that at this site exposure hours were greater during spring, could help explain the negative correlation between density and biomass with water temperature and irradiance, in agreement with [39]. The negative correlation between these two biological variables with irradiance could also be due to a high epiphyte load, as found by [40] for three species of Sargassum in Hawaii. The negative correlation with water temperature is in agreement with [38] [41] [42], among others, and is characteristic of temperate species.

The ephemeral nature of the individual patches of $S$. horneri at RB, could be understood using the physical and biological arguments that have been presented to explain the colonization and establishment patterns of the genus Sargassum: anomalously warm sea water temperatures and their subsequent effects on food web in the region [43]; the disturbance represented by the presence of sand and its negative impact on recruits survival [16]; the unsuitability of smaller stones, gravel and sand, as substrate for grown specimens [7], and highly localized propagule dispersal and settlement [44]. For Gracillaria verrucosa, [45] found than an exponential decline in settlement densities and short dispersal distances was partly due to the diffusive environment found in the shallow subtidal.

The strong seasonality that characterizes the genus Sargassum has been mainly attributed to sea water temperature, and photoperiod, with regional variations due to latitudinal gradients [43] [46]-[48]. “Autumn-fruiting type” and "spring-fruiting type” populations of $S$. horneri have been described for the Seto Inland Sea, Japan by [47]. For both populations it has been considered that the shortening of day length around the autumn equinox, is the possible cue to start the growth phase, characterized by the rapid increase in thallus length. Simultaneously, 
water temperature starts its autumn reduction [47]. However, it is now considered that the difference in seasonality between these two populations does not reflect a phenotypic plasticity, but a genotypic difference [42].

The lifetime of the autumn-fruiting type is considered to have four phases, according to the rates of increase in length and morphogenetic stages: I-formation of early leaves, from December to May; II—differentiation of stems, from May to September; III-rapid elongation of stems and lateral branches, from September to December; IV—-senescence phase, after December. In contrast, the spring-fruiting type has two growth phases and a senescence phase: I—from April to September; II—September to March, and III-senescence phase after March [47]. The selected populations of S. horneri at Todos Santos bay, corresponds to the spring-fruiting type, like the Japanese populations described by [38], and [47] for the Seto Inland Sea, and the populations of S. filicinum, now S. horneri, at Long Beach Harbor [19], and the California Channel Islands [49]. The sampled populations in Todos Santos bay show the lowest density and biomass values, when compared to reported values for $S$. horneri (Table 3).

When we analyzed the effects of the presence of the invasive alga on the local macroalgae community, we were surprised by the fact that at RB, where $S$. horneri was only present a few months and, showed low density and biomass values, there were significant differences between the macroalgae community structure when $S$. horneri was present versus when it was absent. The presence of the invasive algae resulted in significant reductions in macroalgae density, biomass, $S$ and $H^{\prime}$. On the other hand, at RP, where $S$. horneri had a more continuous presence throughout the year, and reached higher density and biomass values, the comparison between the macroalgae community structure under the presence and absence conditions was only marginally significant. The macroalgae showed higher density, biomass, and $H^{\prime}$ when $S$. horneri was present.

It seems that the macroalgae community at RB was more susceptible to invasion, than the one at RP. To understand the invasion process, it is necessary to analyze the number and identity of the functional groups present [2]. At RB there was a loss of functional diversity, with most of the species belonging to the foliose and corticated macrophytes functional groups being present only when $S$. horneri was absent (Table 1), while at RP, most of the species, and functional forms, remained when the non-indigenous alga was present (Table 2).

As indicated by [7], during an invasion process, the community structure is affected by the increasing abundance of the invasive alga, and by the changes in the remaining community. After the invasion of S. muticum in Limfjorden, Denmark, [7] found that members of the coarsely branched and thick leathery algae tended to decrease consistently over time, as a result of competition. Reference [2] found that canopy species, regardless of their density, suppressed invader biomass, while crustose species promoted invasibility. Turf and subcanopy species effects were similar to those of the canopy species, but less intense [2]. Competitive suppression is mainly due to light competition [17] [51] [52] with space competition becoming important in a later stage [52].

At RB, only two species belonging to the leathery macrophyte functional form (canopy) were present, with most of the corticated macrophytes (subcanopy), and all of the foliose (turf), being gone when S. horneri was present. In contrast, at RP, the macroalgae community seems to stand well the presence and abundance of the non-indigenous alga, as most species, and most functional forms remained present, regardless of the presence of $S$. horneri. It is important to note that what we refer to as the local macroalgal community has already being modified, as we found S. muticum at both sites. S. muticum persist under presence or absence of $S$. horneri, so no competition seems to exist between these two species, but this needs to be assessed in the field.

Table 3. Range of values for abundance, density, and biomass reported for Sargassum horneri. Authors are listed chronologically. ND = Not Determined.

\begin{tabular}{|c|c|c|c|c|c|}
\hline Reference & Species & Site & $\begin{array}{l}\text { Abundance } \\
\text { (No. plants) }\end{array}$ & $\begin{array}{c}\text { Density } \\
\text { (No. individuals } \mathrm{m}^{-2} \text { ) }\end{array}$ & $\begin{array}{c}\text { Biomass } \\
\left(\mathrm{g} \mathrm{DW} \mathrm{m}^{-2}\right)\end{array}$ \\
\hline$[38]$ & S. horneri & Obama Bay, Japan & ND & 20 & $\begin{array}{c}680 \text { (sheltered) } \\
431 \text { (exposed) }\end{array}$ \\
\hline$[41]$ & S. horneri & Ohori, Corea & 15 (October) - 68 (March) & ND & ND \\
\hline [19] & S. filicinum & Santa Catalina Island, CA & $\begin{array}{l}\text { >30 (April, exposed) } \\
2 \text { - } 4 \text { (April, sheltered) }\end{array}$ & ND & ND \\
\hline$[50]$ & S. horneri & Gouqui Island, South China Sea & 25 (June) - 830 (August) & 96 (June) - 3320 (August) & $\begin{array}{l}540 \text { (August) } \\
4420 \text { (June) }\end{array}$ \\
\hline This study & S. horneri & Todos Santos Bay, Mexico & ND & 1 (July) - 10 (March) & $3-78$ \\
\hline
\end{tabular}


The already altered macroalgae communities we found inside the Todos Santos bay, are dominated by the articulated calcareous, functional form with the highest biomass at both sites (Figure 4 and Figure 6). This functional form corresponds to what [2] refer to as turf-forming species, which are recognized for being primary space-holders with limited vertical height (usually $\sim 5 \mathrm{~cm}$ length). Algal turf has the ability to monopolize space and persist under a wide range of environmental conditions, and its thickness, rather than its cover, seems to be the most affected by the intensity of disturbance and smothering by sediments [53]. The rapid growth of turfdominated assemblages provides its capability to compete for space and recover from disturbance [54].

\section{Conclusion}

Our results do not fully support our hypothesis. As in RP, where the highest density and biomass values of $S$. horneri were found, there was not the significant reduction in macroalgae density, biomass, $\mathrm{S}$ and $H^{\prime}$ we expected; on the contrary, density, biomass, and $H^{\prime}$ showed higher values when the non-indigenous alga was present (Figure 5). This unexpected result could be due to the fact that the native community had already been altered by the early invasion of $S$. muticum, with the most resilient species and functional forms remaining in place. One of the most important changes we noticed is the severe reduction of the canopy forming species at both sites, confirming the fact that the local macroalgae community has already been modified, in agreement with [7]. A long-term monitoring, with more study sites, is needed to fully comprehend the changes that the local macroalgae communities are experiencing along the Baja California peninsula.

\section{Acknowledgements}

The National Science and Technology Council of Mexico (CONACYT) provided a Master of Science scholarship to G. I. Cruz-Trejo. E. Gil (IIO-UABC) did the topographic work. L. E. Ángeles-Gónzalez, and C. Cabrera (CICESE) helped with data analyses. F. Ponce (CICESE) did the figures. The research was funded with CICESE's internal funding.

\section{References}

[1] Wallentinus, I. and Nyberg, C.D. (2007) Introduced Marine Organisms as Habitat Modifiers. Marine Pollution Bulletin, 55, 323-332. http://dx.doi.org/10.1016/j.marpolbul.2006.11.010

[2] Arenas, F., Sánchez, I., Hawkins, S.J. and Jenkins, S.R. (2006) The Invasibility of Marine Algal Assemblages: Role of Functional Diversity and Identity. Ecology, 87, 2851-2861. http://dx.doi.org/10.1890/0012-9658(2006)87[2851:TIOMAA]2.0.CO;2

[3] Lavorel, S., McIntyre, S., Landsberg, J. and Forbes, T. (1997) Plant Functional Classifications: From General Groups to Specific Groups Based on Response to Disturbance. Trends in Ecology \& Evolution, 12, 474-478. http://dx.doi.org/10.1016/S0169-5347(97)01219-6

[4] Thresher, R. (1999) Key Threats from Marine Bioinvasions: A Review of Current and Future Issues. Marine Bioinvasions. Proceedings of the First National Conference, 24-36.

[5] Schaffelke, B., Smith, J.E. and Hewitt, C.L. (2007) Introduced Macroalgae-A Growing Concern. Eighteenth International Seaweed Symposium, Springer, 303-315. http://dx.doi.org/10.1007/978-1-4020-5670-3_37

[6] Mooney, H.A. and Drake, J.A. (1986) Ecology of Biological Invasions of North America and Hawaii. Springer-Verlag. http://dx.doi.org/10.1007/978-1-4612-4988-7

[7] Stæhr, P.A., Pedersen, M.F., Thomsen, M.S., Wernberg, T. and Krause-Jensen, D. (2000) Invasion of Sargassum Muticum in Limfjorden (Denmark) and Its Possible Impact on the Indigenous Macroalgal Community. Marine Ecology Progress Series, 207, 79-88. http://dx.doi.org/10.3354/meps207079

[8] Norton, T. (1981) Gamete Expulsion and Release in Sargassum Muticum. Botanica Marina, 24, 465-470. http://dx.doi.org/10.1515/botm.1981.24.8.465

[9] Andrew, N. and Viejo, R. (1998) Ecological Limits to the Invasion of Sargassum Muticum in Northern Spain. Aquatic Botany, 60, 251-263. http://dx.doi.org/10.1016/S0304-3770(97)00088-0

[10] Strong, J.A., Dring, M.J. and Maggs, C.A. (2006) Colonisation and Modification of Soft Substratum Habitats by the Invasive Macroalga Sargassum Muticum. Marine Ecology Progress Series, 321, 87-97. http://dx.doi.org/10.3354/meps321087

[11] Deysher, L. and Norton, T.A. (1981) Dispersal and Colonization in Sargassum muticum (Yendo) Fensholt. Journal of Experimental Marine Biology and Ecology, 56, 179-195. http://dx.doi.org/10.1016/0022-0981(81)90188-X 
[12] Critchley, A., De Visscher, P. and Nienhuis, P. (1990) Canopy Characteristics of the Brown Alga Sargassum muticum (Fucales, Phaeophyta) in Lake Grevelingen, Southwest Netherlands. Hydrobiologia, 204, 211-217. http://dx.doi.org/10.1007/BF00040236

[13] Walker, D. and Kendrick, G. (1998) Threats to Macroalgal Diversity: Marine Habitat Destruction and Fragmentation, Pollution and Introduced Species. Botanica Marina, 41, 105-112. http://dx.doi.org/10.1515/botm.1998.41.1-6.105

[14] Ambrose, R. and Nelson, B.V. (1982) Inhibition of Giant Kelp Recruitment by an Introduced Brown Alga. Botanica Marina, 25, 265-268. http://dx.doi.org/10.1515/botm.1982.25.6.265

[15] De Wreede, R.E. (1983) Sargassum muticum (Fucales, Phaeophyta): Regrowth and Interaction with Rhodomela larix (Ceramiales, Rhodophyta). Phycologia, 22, 153-160. http://dx.doi.org/10.2216/i0031-8884-22-2-153.1

[16] Viejo, R.M. (1997) The Effects of Colonization by Sargassum muticum on Tidepool Macroalgal Assemblages. Journal of the Marine Biological Association of the United Kingdom, 77, 325-340. http://dx.doi.org/10.1017/S0025315400071708

[17] Britton-Simmons, K.H. (2004) Direct and Indirect Effects of the Introduced Alga Sargassum muticum on Benthic, Subtidal Communities of Washington State, USA. Marine Ecology Progress Series, 277, 61-78. http://dx.doi.org/10.3354/meps277061

[18] Tseng, C., Yoshida, T. and Chiang, Y.M. (1985) East Asiatic Species of Sargassum Subgenus Bactrophycus J. Agardh (Sargassaceae, Fucales), with Keys to the Sections and Species. Taxonomy of Economic Seaweeds, 1, 1-15.

[19] Miller, K.A., Engle, J.M., Uwai, S. and Kawai, H. (2007) First Report of the Asian Seaweed Sargassum filicinum Harvey (Fucales) in California, USA. Biological Invasions, 9, 609-613. http://dx.doi.org/10.1007/s10530-006-9060-2

[20] Aguilar-Rosas, L.E., Aguilar-Rosas, R., Kawai, H., Uwai, S. and Valenzuela-Espinoza, E. (2007) New Record of Sargassum filicinum Harvey (Fucales, Phaeophyceae) in the Pacific Coast of Mexico. Algae, 22, 17-21. http://dx.doi.org/10.4490/ALGAE.2007.22.1.017

[21] Aguilar-Rosas, L.E., Núñez-Cebrero, F. and Aguilar-Rosas, C. (2013) Introduced Marine Macroalgae in the Port of Ensenada, Baja California, Mexico: Biological Contamination. Procedia Environmental Sciences, 18, 836-843. http://dx.doi.org/10.1016/j.proenv.2013.04.112

[22] Smith, S.V., Ibarra-Obando, S.E., Díaz-Castañeda, V., Aranda-Manteca, F.J., Carriquiry, J.D., Popp, B.N. and Gonzalez-Yajimovich, O. (2008) Sediment Organic Carbon in Todos Santos Bay, Baja California, Mexico. Estuaries and Coasts, 31, 719-727. http://dx.doi.org/10.1007/s12237-008-9054-7

[23] Argote-Espinosa, M., Gavidia-Medina, F. and Amador-Buenrostro, A. (1991) Wind-Induced Circulation in Todos Santos Bay, BC, Mexico. Atmósfera, 4, 101-115.

[24] Alvarez-Sánchez, L., Hernández-Walls, R. and Durazo-Arvizu, R. (1988) Drift Patterns of Lagrangian Tracers in Todos Santos Bay. Ciencias Marinas, 14, 135-162.

[25] Pérez-Higuera, R. and Chee-Barragán, A. (1984) Sediment Transport in Todos Santos Bay, BC. Ciencias Marinas, 10, 31-52.

[26] Bakun, A. (1990) Global Climate Change and Intensification of Coastal Ocean Upwelling. Science, 247, $198-201$. http://dx.doi.org/10.1126/science.247.4939.198

[27] Espinosa-Carreón, T., Gaxiola-Castro, G., Robles-Pacheco, J. and Nájera-Martínez, S. (2001) Temperature, Salinity, Nutrients and Chlorophyll a in Coastal Waters of the Southern California Bight. Ciencias Marinas, 27, 397-422.

[28] Cruz-Colin, M.E. and Cupul-Magaña, L.A. (1997) Erosion and Sediment Supply of Sea Cliffs of Todos Santos Bay, Baja California, from 1970 to 1991. Ciencias Marinas, 23, 303-315.

[29] Castro-Osuna, D.A. (2003) Numerical Simulation of Waves Inside the Todos Santos Bay: Influence of Boundary Conditions. BSc Thesis, Marine Science College. Autonomus University of Baja California, Ensenada.

[30] Guiry, M. and Guiry, G. (2015) AlgaeBase [Internet]. National University of Ireland, Galway.

[31] Steneck, R.S. and Dethier, M.N. (1994) A Functional Group Approach to the Structure of Algal-Dominated Communities. Oikos, 69, 476-498. http://dx.doi.org/10.2307/3545860

[32] Minchinton, T.E. and Bertness, M.D. (2003) Disturbance-Mediated Competition and the Spread of Phragmites australis in a Coastal Marsh. Ecological Applications, 13, 1400-1416. http://dx.doi.org/10.1890/02-5136

[33] Zar, J.H. (1996) Bioestadistical Analysis. Prentice Hall, Upper Saddle River.

[34] Clarke, K.R. and Warwick, R.M. (1994) Change in Marine Communities: An Approach to Statistical Analysis and Interpretation. Plymouth Marine Laboratory, Plymouth.

[35] Oksanen, J., Blanchet, F.G., Kindt, R., Legendre, P., Minchin, P.R., O’Hara, R.B., et al. (2013) Package “Vegan”. Community Ecology Package, Version 2.

[36] Santelices, B. (1977) Water Movement and Seasonal Algal Growth in Hawaii. Marine Biology, 43, 225-235. 
http://dx.doi.org/10.1007/BF00402315

[37] Engelen, A.H., Åberg, P., Olsen, J.L., Stam, W.T. and Breeman, A.M. (2005) Effects of Wave Exposure and Depth on Biomass, Density and Fertility of the Fucoid Seaweed Sargassum polyceratium (Phaeophyta, Sargassaceae). European Journal of Phycology, 40, 149-158. http://dx.doi.org/10.1080/09670260500109210

[38] Umezaki, I. (1984) Ecological Studies of Sargassum horneri (Turner) C. Agardh in Obama Bay, Japan Sea. Bulletin of the Japanese Society of Scientific Fisheries, 50, 1193-1200. http://dx.doi.org/10.2331/suisan.50.1193

[39] Underwood, A. and Jernakoff, P. (1984) The Effects of Tidal Height, Wave-Exposure, Seasonality and Rock-Pools on Grazing and the Distribution of Intertidal Macroalgae in New South Wales. Journal of Experimental Marine Biology and Ecology, 75, 71-96. http://dx.doi.org/10.1016/0022-0981(84)90024-8

[40] De Wreede, R.E. (1976) The Phenology of Three Species of Sargassum (Sargassaceae, Phaeophyta) in Hawaii. Phycologia, 15, 175-183. http://dx.doi.org/10.2216/i0031-8884-15-2-175.1

[41] Koh, C. and Shin, H. (1990) Growth and Size Distribution of Some Large Brown Algae in Ohori, East Coast of Korea. In: Lindstrom, S.C. and Gabrielson, P.W., Eds., Thirteenth International Seaweed Symposium, Springer, Dordrecht, 225-231. http://dx.doi.org/10.1007/978-94-009-2049-1_32

[42] Yoshida, G., Murase, N., Arai, S. and Terawaki, T. (2004) Ecotypic Differentiation in Maturation Seasonality among Sargassum horneri (Fucales, Phaeophyta) Populations in Hiroshima Bay, Seto Inland Sea, Japan. Phycologia, 43, 703710. http://dx.doi.org/10.2216/i0031-8884-43-6-703.1

[43] McCourt, R.M. (1984) Seasonal Patterns of Abundance, Distributions, and Phenology in Relation to Growth Strategies of Three Sargassum Species. Journal of Experimental Marine Biology and Ecology, 74, 141-156. http://dx.doi.org/10.1016/0022-0981(84)90082-0

[44] Kendrick, G.A. and Walker, D.I. (1995) Dispersal of Propagules of Sargassum Spp. (Sargassaceae: Phaeophyta): Observations of Local Patterns of Dispersal and Consequences for Recruitment and Population Structure. Journal of Experimental Marine Biology and Ecology, 192, 273-288. http://dx.doi.org/10.1016/0022-0981(95)00076-4

[45] Norton, T. (1992) Dispersal by Macroalgae. British Phycological Journal, 27, 293-301. http://dx.doi.org/10.1080/00071619200650271

[46] Arenas, F., Fernández, C., Rico, J., Fernández, E. and Haya, D. (1995) Growth and Reproductive Strategies of Sargassum muticum (Yendo) Fensholt and Cystoseira Nodicaulis (Whit.) Roberts. Scientia Marina, 59, 1-8.

[47] Yoshida, G., Arima, S. and Terawaki, T. (1998) Growth and Maturation of the “Autumn-Fruiting Type” of Sargassum horneri (Fucales, Phaeophyta) and Comparisons with the "Spring-Fruiting Type”. Phycological Research, 46, 183-189. http://dx.doi.org/10.1111/j.1440-1835.1998.tb00112.x

[48] Choi, C., Kim, H. and Sohn, C. (2003) Transplantation of Young Fronds of Sargassum horneri for Construction of Seaweed Beds. Journal of the Korean Society of Fisheries and Aquatic Science, 36, 469-473. http://dx.doi.org/10.5657/kfas.2003.36.5.469

[49] Miller, K. and Engle, J.M. (2009) The Natural History of Undaria Pinnatifida and Sargassum filicinum at the California Channel Islands: Non-Native Seaweeds with Different Invasion Styles. Proceedings of the 7th California Islands Symposium, Oxnard, 5-8 February 2008, Institute for Wildlife Studies, Arcata, 131-140.

[50] Zhang, S.Y., Wang, L. and Wang. W.D. (2008) Algal Communities at Gouquil Island in the Zhoushan Archipielago, China. Journal of Applied Phycology, 20, 853-861. http://dx.doi.org/10.1007/s10811-008-9338-0

[51] Sanchez, I. and Fernandez, C. (2005) Impact of the Invasive Seaweed Sargassum muticum (Phaeophyta) on an Intertidal Macroalgal Assemblage. Journal of Phycology, 41, 923-930. http://dx.doi.org/10.1111/j.1529-8817.2005.00120.x

[52] White, L.F. and Shurin, J.B. (2011) Density Dependent Effects of an Exotic Marine Macroalga on Native Community Diversity. Journal of Experimental Marine Biology and Ecology, 405, 111-119. http://dx.doi.org/10.1016/j.jembe.2011.05.024

[53] Airoldi, L. and Virgilio, M. (1998) Responses of Turf-Forming Algae to Spatial Variations in the Deposition of Sediments. Marine Ecology Progress Series, 165, 271-282. http://dx.doi.org/10.3354/meps165271

[54] Airoldi, L. (1998) Roles of Disturbance, Sediment Stress, and Substratum Retention on Spatial Dominance in Algal Turf. Ecology, 79, 2759-2770. http://dx.doi.org/10.1890/0012-9658(1998)079[2759:RODSSA]2.0.CO;2 